岡山大学医学部，解剖学教空（土任：関教授).

Anat. Inst. d. Med. Fak., Univ. Okayama (Vorstand: Prof. M. SEKI).

\title{
ビクトリア青での結織細胞の超生染.
}

\section{Supravitale Färbung der Bindegewebszellen mit Viktoriablau.}

\section{田村良喜 Yoshiki TAMURA.}

〔昭和 28 年 6 月 11 日鿌稿受付.〕

先の報告 (1952) スアルコール溶性染料なる中等極性のビクトリア青が 白血球，殊にリンパ球と単球内の粘子と糸粘休をよく超生染することを斯 いた，続いて私は二十日鼠の皮下結織を取り，ビクトリア青で超生染して 諸細胞を観察した。同時に中性赤とヤーヌス緑を以て組織を超生染して比 較観察し，な持中性赤とビクトリフ青の混合溶液ででも超生染して結果を 比較することを試みた。

\section{I. 材料と方 法.}

先ず $5 \%$ \%コールを以て $0.1 \%$ クトリア青溶液を作り，その $0.1 \mathrm{cc}$ を Ringer 氏液 100 中に混じて $0.01 \%$ ビクトリア青溶液を作る . 但し $\mathrm{NaOH}$ を加えて pH 7.5一8.0 としたレチチン（卵からの）飽和溶液 1 滴 を予め1 100の Ringer に入れてよく混ぜて置く.これは溶けたビクトリナ 青分子の凝結を防ぐためである。二十日鼠の背部の毛を剃り，そこの皮煵 を大豆大に切除して直ちにとの裏面にある皮下結織を鈎ピンで挾んで挙上 し，その小塊を鋏で切り取り，前記染料溶液に投入し，少し広げて染料が

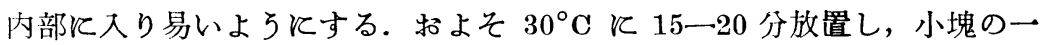
部を切り出して, 清拭した載せ硝子の上で軽く伸展し, 直ちに被いガラス をして，周用を白色ワゼリンで緑封した，特に線維細胞，線組球，組織球， 単球の染色の状況が钼察された.

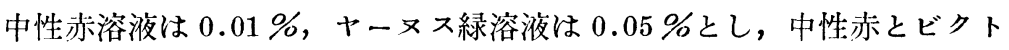
リア青の混合溶液は $0.01 \%$ 中性赤溶液 $1 \mathrm{cc}$ にレチチン加 $0.02 \%$ グクリ ア青溶液 2 滴を加えたるのを使用した。これ等の染料溶液を作るには専ら Ringer 氏液を用いた。ビクトリア青としては戦前の Grübler 社の Victoriablau 4R n. Lustgarten がよいが, 戦後の Merck 社の Viktoriablau も役立 つ. 中性赤は戦前の Merck のもの, ヤーヌス緑は最良と云われる戦前の I. G. Farbenindustrie Aktiengesellschaft の Janusgrün B が用いられた. 


\section{II. 結果と考察.}

\section{a）ビクトリア青での溇生染.}

二十日鼠の皮下結織をビクトリフ青で 15-20 分間超生染して鏡検する と，線維細胞は図 1 飞示されたように，胞形質は殆んど逶明無棑造で，そ の輪邡の認めにくいものが多い。核は多くは卵円形で，概ね他の細胞のも のに比較して大であるが，時に核がやや小で，円形のものもある．核のう ちには核小体と思われるすのを 2一数個見ることがある.

線維細胞の胞形質内に，殊飞核の周りに薄青に染った糸状や杆状や点状 のものが数一数 10 個現われる. 時飞㤥の一側に多いこともある. 糸状ま たは杆状のるのは長さ $1-2 \mu$ までで, 時に中央部が少しく膨れたもの， また㐿端が膨れて亚鈴状となったものがある。これ等の系状または杆状の あのは時とともに減じ，凡そ 1 時間を過ぎれば殆ど無くなり，その代りに 点状のものが多くなる，乙れ等の青染物象はその大さと形と，又それ等が 時とともに変化すること等から，少くす大部分は疑いなく糸粒体である。

線維細胞の糸粒体の染色は杆状のものよりも点状のものの方が濃いよう である。線維細胞の脂肪滴は Zweibaum と Elkner (1930) もZ゙ったよう に甚だ少く，また空胞も稀である.

これ等の線維細胞のほかに図 2 の如く，大小不同の青染粒子を持つもの があり，これは線維㽗胞と組織球の移行形の線組球である。線組球の輪漷 は線維細胞のものよりは明かで，核は多くは類山形である。青染精子は核 の凮用に小型のものが多く，外方飞移るにつれて大形のものが加り，即ち 大小の䊀子を兒るようになる，小形の粒子も多くは線維細胞で見た点状の 系粒体よりも大で，大形の粒子の5ちには点状の糸粒体の 2 倍以上の大き さのものもある．線維細胞に見たような青い系状や杆状のものは殆ど見当 らない，線組球の上記の青染物象は後のヤーヌス緑での超生染の所見から 推して.小形の精子の大部分は糸精休であり，大形のものは膨れた糸粒体 または類脂質を多く有する䊉子または小滴か空胞かであると思はれる.

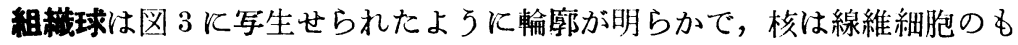
のよりもやや小さいことが多い。組織球の著しい特徵は胞形質内に大小種 ßの青く染った粒子と少しも又は少ししか染らぬ空胞が数多く散在するこ とである。青く染った大きな粒子は多くは不正球形で，その内に多数の濃 染した小粒子の含まれることがある．小さな粒子と云ってもその大多数は 線維細胞等の糸粒体よりもよほど大である. 即ち組織球には糸粒体はあっ ても甚だ少いものと思える。

巽球を四 4 に示す．絬合組織内で単球と呼ばれるものは，血液中に見る 
ものと全く同じいか又は近似するもので，類球形のととが多く，大さは小 リンパ球より大きいととは勿論，中リンパ球よりるやや大きいが，組織球 よりは小さく，輪部が甚だ明膫である。核は腎形または類球形を呈する。 他の染色法で単球と小形の組織球を分別する際に最も役立つ標識は, 単球 には少数の微小の粒子と時飞小空胞があっても，粗大な粓子と大空胞がな く, 組織球にそれ等（大小の粒子と空胞）が多数あることである. ビクト リフ青で超生染せられた単球にても青色飞染色した小さな粒子が 10 数個 から 40一50 個現われる. その粒子は大部分が核の陌凹側に压花形をし て集ったり，2-3 所飞群を作ったり, また胞形質の全域に散在性にあっ たりする．時に大粒子の周りを点状の小粒子が取巻くよ5飞存在するのが 見られる。一般に大粒子は小粒子飞比較して染る度が強い様である。

上記の単球のビクトリフ青で超生染する粒子のうち甚だ小形のるのは後 述のヤーヌス緑での超生染の所見と比較して糸粒体と推定せられ.大粒子 は類脂質を多く有する蓄滞積物質と小滴，また一部は空胞である万，上記 のよう飞，単球の青染した大粒子が中性赤で超生染した血液単球によく見 る如く核の一側集っててほぼ花形を作るのが兒られることがあり，この 花形の大粒子の少くも一部は中性赫で超生染するときに，やはり怰の修ら で赤染する空胞と同一物であろろ。

\section{b）中性赤ての超生染.}

中性赤での結織細胞の超生染は昔からよく行われて居り，特に新しく見 られる事尘はないが，ビクトリフ青での超生染の結果と比較するためには 簡単ながらここにとの所見を記載する必要がある。ついでと中性赤で染め られた細胞の種類の判断に云及しなければならない。

線維細胞には中性赤飞染る粒子をたは空胞が少く，小さなるのが僅かに 数個である. 染らぬ空胞も稀にある.

線粗球(図 5)は胞形質の全域に互って大小の赤い粒子をやや数多く現わ す．超生染の時間の経過とともに粒子の增大增数することは既によく知ら れている。健常の組織から取られた線組球とは初め不染の空胞が稀飞見ら れるのみである. 線組球の中性赤粒子がビクトリフ青粒子ょりる少いのは, 前者が蓄積したり㴆積したりした物質の精子と空胞のみであり, 後者には それのみならず糸粒体が染って加っているからである.

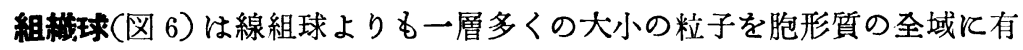
し，著しく大きい粘子があるので目立つ. 大粒子は慨ね濃染する。な和不 染と淡染の空胞が少くなく, 空胞のうちには著しく大きいるのがある.

以上の細胞種の間には移行があるが，分別は大体容易である．分別飞㷴 


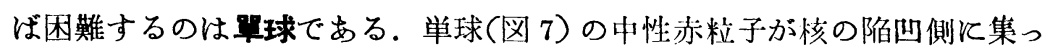
て花形をするのがこの細胞殆んぞ特有であるが，花形はこの細胞が盛ん 飞運動するときと，漸炊肥大して組織球に移行するときと分散し，中性赤 粒子は胞形質の全域飞広がる。即ち単球は花形を持つが，常に花形を持つ とは限らないのである。

c) ヤーヌス稌での超生染.

ヤーヌス緑の分子は管て関（1933）が注意したように，易く凝結し，易 く物象に吸着し, 類脂質にはあまりよくは溶けない塩基性染料であり, 密 構で内部表面の多いと思える系粒体飞比輷的多量飞吸着せられる。

線維緙胞(図 8) では系状, 杆状, 点状の糸粒体が数一数 10 個現われ, これはビクトリア青での超生染のときと殆ど逢わないが，物象の染色がビ クトリフ青の場合よりも概して少しくやや濃い。

線組球(汹 9)には線維細胞で見たような点状の糸粒体が現れるが, 系状 や杆状のものは稀である. 系粒体には点状のもののほかにやや大きいもの が混在する。染色液にヤーヌス緑が濃過ぎれば，系粘体のほかと大きい蓄 滞樍の精子が染って現れ，見分けがつかなくなる。

培養せられた組織の組維球には，例えば Carrel と Ebeling (1926)の名 著に見るように, ヤーメス緑で糸粒体がよく現わされる。しかると動物体 内の組織球(図10)とはヤーヌス緑で証明せられる糸粒体が比較的少く, 甚 だ屡ばその存在の証明せられねるのがある. 上記の上うと染色液にヤーヌ ス緑が濃いと系粒体以外の粒子が染り, これが系粒体と混視せられ易いか ら，研究者自らも，また他人の所兒飞も注意しなければならぬ.

草球(罒11)ではヤーヌス緑に染る系粒体は点状であり, 胞体内の一所に 集ることがあり，また全域に散在することがある。単球の組織球に移行し ようとするものとは系粒体は常に散在する.

\section{d）ビクトリア毒と中性赤の伍用染色.}

中性赤とヤーヌス緑が伍用せられるのに做い，ビクトリア青を中性赫に 伍用して超生染することを試みた。 線組球でる単球でる, 像は大体中性赤 とヤーメス緑を伍用した場合のものと似る. 線維細胞とは主とビクトリフ 青で染められた粒子のみ, 組織球には主に中性赤に染められた粒子と空胞 のみが現れる。

\section{III. 結落.}

二十日鼠の皮下の結織細胞を類脂質の最良染料であるビクトリア青で超 生染し，これを中性赤とヤーヌス緑で趋生染する結果と比較した。ビクト 
リフ青は糸粒体を染め，その他蓄積または滯積した物質の粒子と空胞の類 脂質を多く含むと思えるものを染める，糸粒体のビクトリア青で染まる強 さはヤーヌス緑でのものと僅かながら少る.

\section{Autoreferat.}

Die Bindegewebszellen aus dem subkutanen Gewebe der Maus wurden mit dem besten lipoidfärbenden Farbstoff Viktoriablau supravital gefärbt, und die Resultate wurden mit denen der supravitalen Färbung mit Neutralrot und Janusgrün verglichen. Das Viktoriablau färbt die Mitoshondrien und daneben auch solche gespeicherte und gestapelte Granula und Vasuolen, die viel lipoide Substanzen enthalten. Die Färbungsstärke der Mitochondrien mit Viktoriablau ist etwas schwäsher als die mit Janusgrün.

\section{文献.}

Carrel, A. a. A. H. Ebeling: 'The fundamental properties of the fibrotlast and the macrophage. II. The macrophage. J. of exper. Med. 44 (1926). S.эki, M.: Zur Kenntnis der intra- und supravitalen Färbung. IV. Umladbarkeit der basischen Vitalfarbstoffe als eine wesentliche Vorbedingung für das Eindringen derselben in die Zellen; Bedeutung der Flockbarkeit der Farbstoffe. Z. Zellförsch. 19 (1933). - Tamura, Y.: Supravitale Färbung der Kaninchenleukocyten mit einem mittelstark polaren Farbstoff, Viktoriablau. Arch. hist. jap. 3 (1952). - Zweibaum, J. et A. Elkner: Les structures cytoplasmiques et L'appareil de Golgi dans les cellules cultivés in vitro. Arch. exp. Zellforsch. 9 (1930).

\section{附 図 說 明.}

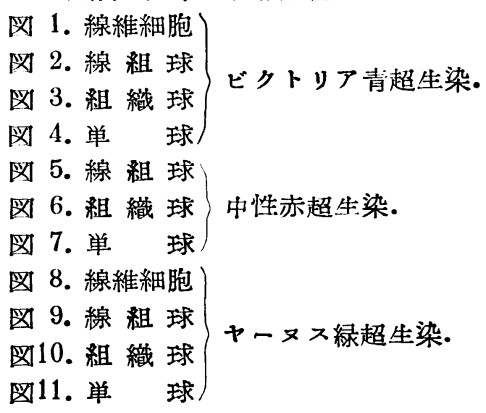

\section{Erklärung der Tafelabbildungen.}


mit Viktoriablau.

Abb. 1. Fibrocyten

Abb. 2. Fibrohistiocyten

Abb. 3. Histiocyten

mit Viktoriablau gefärbt.

Abb. 4. Monocyten

Abb. 5. Fibrohistiocyten

Abb. 6. Histiocyten

Abb. 7. Monócyten

mit Neutral rot gefärbt.

Abb. 8. Fibrocyten

Abb. 9. Fibrohistiocyten

Abb. 10. Histiocy ten

Abb. 11. Monocyten

mit Janusgrün gefärbt. 


\section{田村良喜}
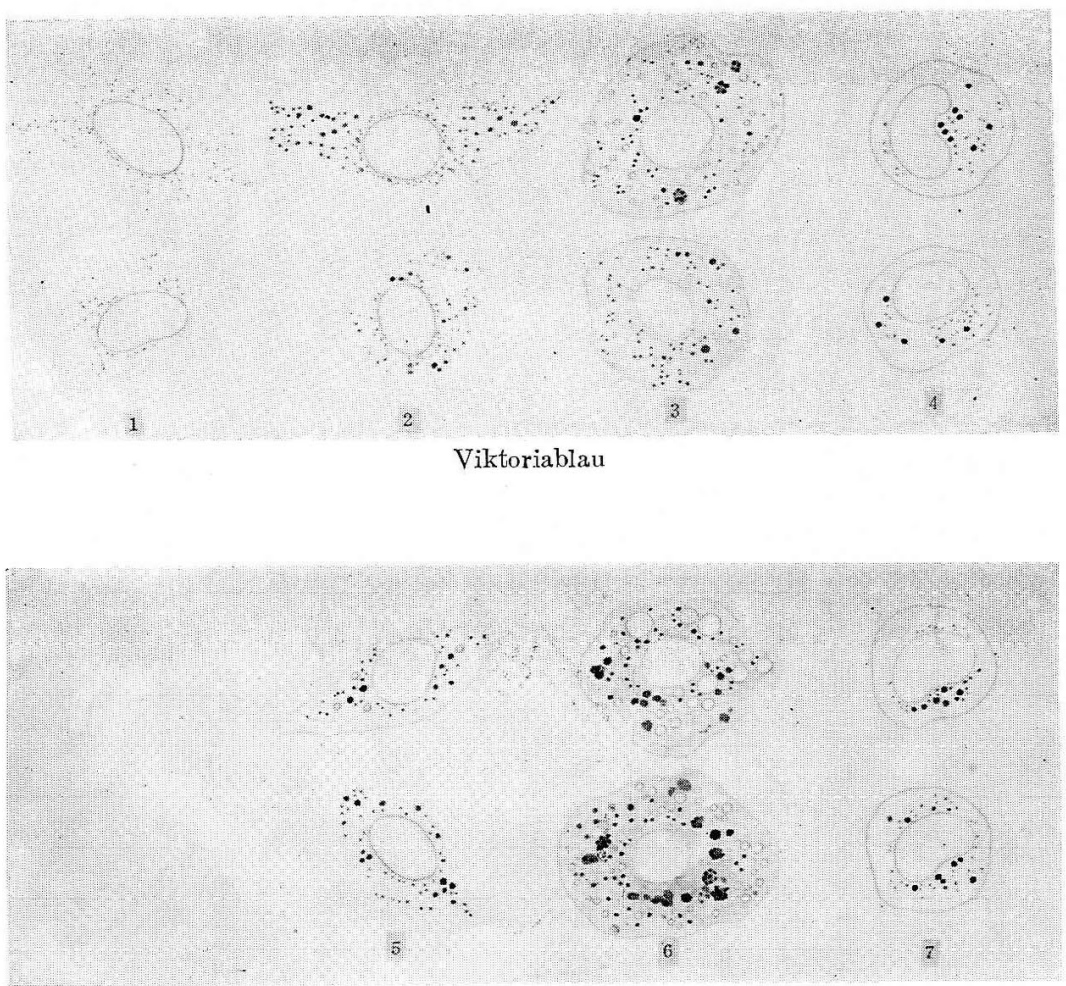

Neutralrot

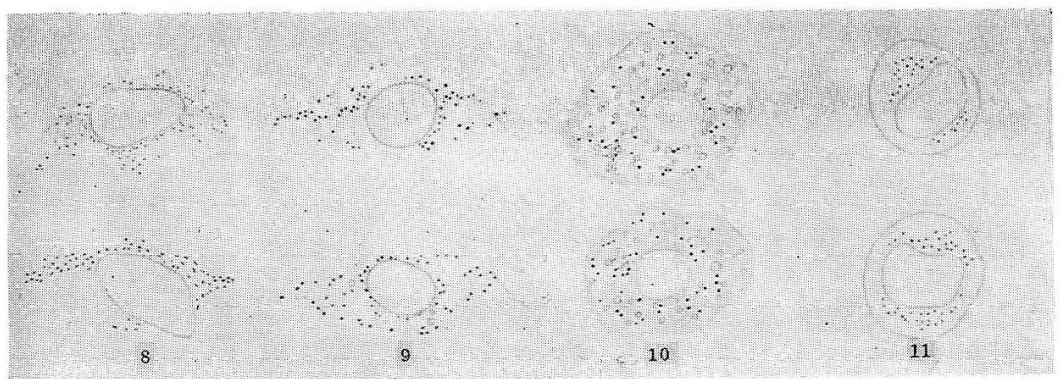

Janusgrün 